\title{
IS WOMEN'S JOB SATISFACTION HIGHER THAN MEN'S? SELF-SELECTION, EXPECTATIONS OR UTILITY FUNCTION
}

\author{
Nuria SÁNCHEZ-SÁNCHEZ - Adolfo C. FERNÁNDEZ PUENTE
}

(Received: 22 May 2017; revision received: 7 November 2017;

accepted: 25 June 2018)

This paper examines the paradox between high relative levels of job satisfaction and the characteristics of women's jobs compared to men's in Spain. Three hypothesis are considered: i) the existence of a selection bias when participating in the labour market; ii) of the presence of adaptive job satisfaction; and iii) the existence of differences related to preferences of different nature to strictly labour issues.

The study shows that, although having lower working conditions, women are more likely to be satisfied at work than men are. This paradox persists regardless of the inclusion of a great range of variables of different nature (objective and subjective), the age group and educational level under consideration. The Oaxaca-Blinder decomposition suggests that women's preferences are actually influencing the differences in job satisfaction. However, it is not demonstrated that these differences disappear as age decreases or educational level increases. The probable existence of a "glass ceiling" that prevents women from having access to posts of greater responsibility and higher wages could cause that women who actually reach them are more satisfied than their male colleagues. As the labour market and society become more equal, this paradox might dilute.

Keywords: satisfaction, self-selection, expectations, working conditions, personal development

JEL classification indices: J01, J16, I30

Nuria Sánchez-Sánchez (corresponding author), Professor at the Department of Economics, University of Cantabria, Spain. E-mail: sanchezn@unican.es

Adolfo C. Fernandez Puente, Professor at the Department of Economics, University of Cantabria, Spain. E-mail: fernanac@unican.es 


\section{INTRODUCTION}

The economic literature devoted to the determinants of job satisfaction has been extensive in the last two decades. One of the issues that has attracted the most interest has been the existence of differences in job satisfaction between men and women. Although the studies have shown mixed results, most of them conclude that the level of satisfaction of women is higher than that of men. This higher satisfaction is paradoxical, since the study of working conditions in terms of wage gap and employment segregation shows a clearly unfavourable situation for women, which does not seem to imply penalization in terms of job satisfaction.

Part of the differences in satisfaction levels are due to an incorrect selection of the variables included in the analysis (Clark - Oswald 1996; Sloane - Ward 2001; Kifle et al. 2014). If the objective and subjective characteristics of the job, as well as those of the worker, are not considered adequately, a bias may be incurred and the variables "man" and "woman" would collect other information that is not strictly related to sex. Additionally, the results do not appear to be homogeneous across different age cohorts and educational levels. In fact, there appears to be a lower difference in satisfaction by sex among younger workers with a higher educational level. The labour market conditions of each country also seem to determine the differences in satisfaction levels, not only in the differential between men and women, but also in the positive or negative impact. In fact, studies related to the Spanish labour market show contradictory results.

This disparity of results precisely justifies our work. Thus, a detailed analysis of the differences in job satisfaction between men and women in the Spanish labour market is offered, including their personal characteristics and the objective and subjective characteristics of their jobs. In addition, the sample is firstly disaggregated according to the age group and, secondly, to the worker's educational level to verify whether differences in satisfaction levels persist, even when self-selection bias is reduced.

The analysis includes several novel aspects. First, the period considered, 2006-2010, includes two years in which the economic crisis had a strong impact on the Spanish labour market. In this period, far from being reduced, female activity rates increased and converged with those of males. ${ }^{1}$ This convergence will testify a reduction in the differences of self-selection bias between men and women. Second, estimations include, as independent variables, subjective labour characteristics, as well as satisfaction with housework. Thereby, estimates re-

1 Female activity rate rose from 48.5 to $52.7 \%$, while male activity rate dropped from 69.2 to $68.2 \%$ according to Labour Force Survey (hereafter EPA) published by the National Statistics Institute (hereafter INE). 
flect, more closely, the differences in job satisfaction attributed inherently to sex. ${ }^{2}$ Lastly, the sample has been disaggregated by age and educational levels, since it is precisely in the groups of younger and more educated people where the differences between men and women participation in the labour market are smaller.

The article is structured as follows: After this introduction, the theoretical framework that justifies the existence of differences in satisfaction levels by sex is developed in the second section. The third section describes the data, the methodology and the theoretical model used in the analysis, while the fourth shows the econometric results. Finally, conclusions are offered in the fifth section.

\section{THEORETICAL FRAMEWORK: JOB SATISFACTION AND SEX}

Clark's seminal work (1997) approached, for the first time, the issue of differences between job satisfaction of women and men. It opened a new field of research that aims not only at measuring its existence, but also at finding their origin.

Despite mixed results, most of the studies demonstrate a positive difference in job satisfaction between women and men (Clark 1997; Sloane - Williams 2000; Souza-Poza - Sousa-Poza 2000a, 2007; Long 2005). The reasons given to justify this differential are mainly: i) the existence of a selection bias when participating in the labour market; ii) the presence of adaptive job satisfaction; and iii) the existence of differences related to gender and activities that have traditionally been done by men and women, which are of different nature to strictly labour issues.

The first hypothesis is that there may be a selection bias that provokes that only women with greater motivation participate in the labour market, and it is the same higher motivation which would make them feel more satisfied. Carleton - Clain (2012) incorporate this idea, arguing that selection bias could be caused by a woman's marital status. In principle, married women could have additional resources from their husbands and therefore, greater discretion when starting or staying in a job. If this hypothesis is true, then married women who work would do it to a large extent because they wish to and would be more satisfied in their jobs (otherwise they would give them up). The authors add that in the case of married men, mobility is more reduced, as would be the aggregate satisfaction levels. The results of their work corroborate this idea by observing greater satisfaction in women than men, exclusively when married people are considered.

2 Kayser (2007) considers satisfaction with safety at workplace and with hours worked as dependent variables, but not as explanatory ones, which may overestimate the coefficient of women's total job satisfaction. 
Sousa-Poza - Sousa-Poza (2007) noted that in the Swiss labour market job dissatisfaction does not lead to expulsion from the labour market but causes a change in the job, i.e. greater job rotation. In the case of Spain, the male activity rate exceeds by more than 12 percentage points the female activity rate ${ }^{3}$, so it can be argued that there is a bias in market participation and it is possible that it could be related, among other factors, to motivation. In principle, participation would depend on the woman's personal circumstances, but also in many cases on the real possibilities of entering the market, which in turn depend on age, education and effective discrimination when recruited. Being older, having lower education than required or being discriminated when recruited could lead to leaving the labour market, thereby the remaining exclusively younger and more qualified people with higher chances of being recruited are being more satisfied.

If this hypothesis is true, the satisfaction levels of men and women with the same educational level should be similar. ${ }^{4}$ Since in Spain the level of education between men and women has tended to converge over time, satisfaction levels should also be the same, at least for younger people. The study of official data evidences a clear convergence in the rates of activity by age ${ }^{5}$ and education ${ }^{6}$. Therefore, disaggregation by ages and levels of education would reduce the selfselection bias.

In this line, Clark (1997) and Donohue - Heywood (2004) concluded that sex differences disappeared for younger people and those with a higher educational level. However, Bender - Heywood (2006) pointed out that even at higher educational levels women were more satisfied than their male colleagues.

The second hypothesis is based on women's lower job expectations. The justification would be that women have traditionally been in the worst position in the labour market, which would be associated to lower job prospects. Thus, lower working conditions would affect women to a lesser extent than men and their satisfaction, ceteris paribus, would be higher, since they would internalize the difficulties they face to get the job.

3 See the corresponding data of EPA published by INE.

4 The effect that discrimination could have at the moment of recruiting will not be removed.

5 Women's activity rate ranges from $48.9 \%$ in the $55-59$ age group to $85.1 \%$ in the $25-29$ age group according to INE in 2010. Thus, in the first group the difference between female and male activity is almost 31 percentage points and, in the second one it is only 4 . Throughout the period, an increase in the activity rates is observed in all groups.

6 Activity rates of women with higher vocational training certificates and university and postuniversity studies are significantly higher than those of women with lower educational levels. Moreover, female activity rates are bigger than those of men at those educational levels according to INE. Therefore, in these strata of population it could be concluded that self-selection bias does not exist, or that, at least, it is comparable to that of males. 
This situation, once again, should be transitional in the event that an equality of working conditions between men and women might occur over time. It is possible to assume that the equality level of working conditions is higher among the younger and more qualified people (Sousa-Pouza - Sousa-Pouza 2003). Therefore, one would expect that sex does not affect job satisfaction levels in the group of younger and more qualified people. Sloane - Ward (2001) corroborated this idea by focusing their study on university professors, a stratum where education levels by sex were more equal. Green et al. (2016) confirmed this hypothesis in the case of the UK by obtaining that satisfaction levels of younger and more qualified workers of both sexes are similar. In short, they concluded that the paradox is a temporary phenomenon that is bound to disappear gradually over time in markets at which the levelling is happening.

The third and last hypothesis is based on the existence of differences in satisfaction levels or preferences related to gender. This line of argument would be justified by biological reasons, which are beyond our analysis, or because women will include within their work utility function other aspects of their personal and family life to a greater extent than men. Since women most often take care of the children, dependents and even the household chores, satisfaction with these activities could impact job satisfaction (Borra et al. 2007). In this line, Bender et al. (2005) attributed a higher job satisfaction of women to a greater flexibility in their work, which will be chosen by the worker herself to reconcile with other personal or family aspects. Sloane - Williams (2000) denied, in fact, that there could be any intrinsic qualities in women associated with their greater job satisfaction. They attributed satisfaction differences to self-selection of jobs with different characteristics. Thus, men would value to a greater extent getting a higher wage, while women would show a greater preference for other variables, such as flexibility or work environment. Bender et al. (2005) showed, in fact, that if work flexibility is taken into account, the differences in job satisfaction associated with sex disappear. Since many studies include the wage level, but not the latter variables, satisfaction bias in term of satisfaction will continue in favour of women.

In any case, to corroborate at least partially each of the hypotheses, it would be necessary to consider, apart from the objective and subjective characteristics of the job, educational levels, age of workers and other variables associated with the workers' family and personal environment.

At an aggregate level, labour market conditions in each country also seem to determine the differences in satisfaction between men and women. Research in Spain are scarce and the conclusions are disparate. Alvarez (2005), Kaiser (2007), Rico (2012) and Hauret - Williams ${ }^{7}$ (2017) indicated that women's satisfaction is

Spain is not analysed separately as it is included in the group of Southern European countries. 
higher than men's, while Mora - Carbonell (2009) concluded that women's satisfaction is lower than their male colleagues' ${ }^{8}$. However, Sousa-Poza - Sousa-Poza (2000b) and Gamero (2004) concluded that there are no significant differences between the two sexes. None of the mentioned studies considered the period of 2006-2010, in which the Spanish labour market conditions drastically changed due to the impact of the economic crisis.

\section{SOURCES AND METHODOLOGY}

Research on job satisfaction in Spain has been scarce mainly due to the lack of data. Euro-barometer surveys are often used, but the sample size for each country is rather small (1000 participants) and the included covariates are too limited to carry out any extensive and robust analyses. The European Community Household Panel Survey contains information on job satisfaction but it stopped in 2001, substituted by a survey with reduced information.

The only available Spanish data with a reasonable sample size, which includes information on job satisfaction, is the Spanish Survey of Life Quality at Work (SLQW). The survey is conducted on more than 7000 Spanish workers each year starting from 1999. Our study focuses on five cross-sections of the SLQW survey for the years of 2006-2010 $0^{9}$. The main advantage of the survey is that it includes workers' self-reported satisfaction scores in different job domains as well as overall job satisfaction, along with the information on important worker and job characteristics. Unfortunately, the survey is not longitudinal; therefore it is not possible to examine the factors affecting transitions in satisfaction level or to control for the fixed individual effects.

At the outset, it is important to verify the satisfaction questions. The respondents in the survey were asked "How satisfied are you with your job (or different job aspects)?" with 10 possible response categories ranging from 'very dissatisfied' (=1) to 'very satisfied' (=10). The responses are based entirely on individuals' own perception. The question asked is not concrete in terms of comparison groups or in the description of each category of satisfaction levels ${ }^{10}$, therefore leaving a large room for interpretation of heterogeneity across interviewees. An-

8 Their research is focused exclusively on the region of Catalonia for the case of university lecturers.

9 Although survey data is available since 1999, there were some methodological changes which make the data incomparable between pre and post 2006 periods. The survey was discontinued in 2011 as a result of budget cut by the government.

10 The categories $(2,3,4, \ldots, 9)$ between the worst $(=1)$ and the best $(=10)$ have no words attached to them. 
other characteristic to note is that the responses are ordered qualitatively ${ }^{11}$. Comparing the responses between the groups of people is not straightforward. The analysis begins with simple "averages" of the responses. The simple average provides a satisfaction index which is comparable across year or population under the assumption of linearity across the response category.

In Appendix 1 the set of variables used, their definitions, how they are measured, their average and standard deviations are shown.

Regarding the theoretical model, it is based on an individual work utility function for each worker, which adopts the term used by Clark - Oswald (1996):

$$
u=u(x, j, f l),
$$

where $x$ includes variables related to the worker's individual characteristics, $j$ represents variables related to the job characteristics, both objective and subjective, and $f l$ denotes variables related to work flexibility and family life conciliation.

To estimate the model, it is assumed that job satisfaction can be used as a proxy of individual work utility so the following model is proposed:

$$
J S_{i}^{*}=\beta X_{i}+\alpha J_{i}+\gamma f l_{i}+\varepsilon_{i} .
$$

Job satisfaction $\left(J S^{*}\right)$ is a latent variable that denotes individual's probability of being satisfied at work. This variable is unobservable, and for its measurement an ordinal assessment made by the individual himself is used. The relationship between the latent variable and our job satisfaction variable is shown by the following expression:

$$
S L_{i}=\left[\begin{array}{ccc}
0 & \text { if } & J S_{i}^{*} \leq \mu_{0} \\
1 & \text { if } & \mu_{0}<J S_{i}^{*} \leq \mu_{1} \\
2 & \text { if } & \mu_{1}<J S_{i}^{*} \leq \mu_{2} \\
& & \\
& & \cdots \\
10 & \text { if } & \mu_{10} \leq J S_{i}^{*}
\end{array}\right]
$$

where $\mu$ represents the values of latent job satisfaction, which define the observed job satisfaction intervals. It is assumed $\mu_{0}=0$.

11 To the extent that respondents considered the response numbers (1 to 10) as cardinal measures of their satisfaction (for example, the response 10 means twice more satisfied than the response 5), the reported values may be used as a cardinal measure of satisfaction. However, many studies have shown virtually no qualitative differences in empirical results between different treatments of the variable. 
Since the values of the dependent variable are ordered, an ordered probit model is used. The values of the variable measuring job satisfaction have been grouped into three categories: the value 0 expresses low satisfaction (values $0-4), 1$ average satisfaction (values 5-7) and 2 high satisfaction (values 8-10). The purpose of the group is twofold. On the one hand, the results will be easier to interpret. On the other hand, part of the subjective component a person has when assigning a specific value to their job satisfaction is eliminated. For the interpretation of the results marginal changes in each category are estimated, so that the change is reflected in the probabilities by estimating the marginal changes of each explanatory variable.

The marginal effect corresponds to the slope of the curve relating the dependent variable $x i$ with the probability that the observed job satisfaction takes the value $j$ conditioned to $x i$, keeping all other variables constant. In short, the curve relating $x i$ with $\operatorname{Pr}\left(J S_{i}=j \mid x_{i}\right)$, where $\mathrm{j}=0,1,2$, since it only takes three values. The results are the marginal effects when job satisfaction takes the maximum value $(2)^{12}$.

Finally, the method of Oaxaca-Blinder (1973) is also used to disaggregate the observed differences in satisfaction levels between men and women into two components: the component attributable to the characteristics of the job done by both and the component corresponding to the performance of each of those characteristics obtained by men and women.

In this case as a non-linear model is used, the conditional expectations of the characteristics may differ from the characteristics themselves (Oaxaca - Ransom 1994). Therefore, the conventional decomposition equation is redefined in terms of conditional expectations performing the following breakdown:

$$
\begin{aligned}
& J \bar{S}_{F}-J \bar{S}_{M}=\left[E_{\beta^{*}}\left(J S_{i F} \backslash X_{i F}\right)-E_{\beta^{*}}\left(J S_{i M} \backslash X_{i M}\right)\right]+ \\
& {\left[E_{\beta_{F}}\left(J S_{i F} \backslash X_{i F}\right)-E_{\beta^{*}}\left(J S_{i F} \backslash X_{i F}\right)\right]+} \\
& {\left[E_{\beta^{*}}\left(J S_{i M} \backslash X_{i M}\right)-E_{\beta_{M}}\left(J S_{i M} \backslash X_{i M}\right)\right] }
\end{aligned}
$$

where $\beta^{*}$ is defined as a weighted average of the coefficient vectors $\beta_{F}$ and $\beta_{M}$ :

$$
\beta^{*}=\Omega \beta_{F}+(I-\Omega) \beta_{M}
$$

$\Omega$ is a weighting matrix and I is an identity matrix.

The left side of equation (4) represents the differential of average satisfaction between women and men. The right side depends on different assumptions about $\Omega$. In this work two values of $\Omega$ are considered. If $\Omega$ is equal to an identity matrix,

12 Refer to the authors to request estimates for the values 0 and 1. 
then the right side of the equation reflects the aggregation of two components: the one attributable to the characteristics of the job done by both women and men, and the one corresponding to the performance of each of those characteristics obtained by men and women. The coefficients estimated would be the ones of women. In contrast, if $\Omega$ is considered as a null matrix, then the coefficients would be the ones for men. Sinning et al. (2008) model is followed for the econometric analysis.

\section{RESULTS}

Table 1 shows the average satisfaction of men and women, according to their personal and job characteristics of objective nature, as well as the number of observations in each group. ${ }^{13}$ The observation of these data allows a first approach of sex differences and the influence of other factors on the satisfaction level. As can be seen, the differences in satisfaction levels are virtually non-existent, at least when the entire sample is considered ( 7.35 in women compared with 7.28 in men $)^{14}$. With regard to age, there are not too many differences by sex. It is also observed that satisfaction increases with age, being in both cases, the workers over the age of 60 have higher satisfaction rates ${ }^{15}$. In addition, separated or divorced people have lower satisfaction rates than married people, as well as people with children, compared to the whole sample.

The educational level has a direct and positive effect on satisfaction of both men and women. The workers with university and post-university studies are the most satisfied while the less literate workers are the least so. In addition, having a managerial or intermediate post with subordinates provides greater satisfaction than being an employee or self-employed. Public sector workers are also more satisfied than those in the private sector, especially in the case of women. ${ }^{16}$

Workers with temporary and part-time contracts are less satisfied than the average and this situation is particularly so in the case of men. This could be justified by Carleton - Clain (2012), who argue that women, if they have an alternative family income, would be ready to accept inferior working conditions, associated with instability, to a greater degree. At the same time, part-time jobs allow, to a

\footnotetext{
13 The number of observations in each group is of great interest when analysing the significance levels of the estimates.

14 A test for the comparison of means between satisfaction of men and women is performed and the results show that there is no significant difference between them.

15 Note, in any case, that this group of workers represents just about $4.3 \%$ of the sample.

16 In this group of workers, women are more in numbers than men.
} 
Table 1. Mean and standard deviation of job satisfaction scores for each category

Job satisfaction

\begin{tabular}{ccc} 
Total & Women & Men \\
\hline 7.31 & 7.35 & 7.28 \\
39,407 & 16,652 & 22,755
\end{tabular}

Personal characteristics

\begin{tabular}{|c|c|c|c|}
\hline \multirow[t]{2}{*}{ Age $<30$ years old } & 7.30 & 7.30 & 7.23 \\
\hline & 6,498 & 2,937 & 3,561 \\
\hline \multirow[t]{2}{*}{ Age $30-40$ years old } & 7.27 & 7.27 & 7.28 \\
\hline & 11,472 & 5,070 & 6,402 \\
\hline \multirow[t]{2}{*}{ Age $40-50$ years old } & 7.29 & 7.32 & 7.27 \\
\hline & 12,028 & 5,137 & 6,891 \\
\hline \multirow[t]{2}{*}{ Age $50-60$ years old } & 7.31 & 7.33 & 7.31 \\
\hline & 7,710 & 2,897 & 4,813 \\
\hline \multirow[t]{2}{*}{ Age $>60$ years old } & 7.56 & 7.53 & 7.58 \\
\hline & 1,699 & 611 & 1,088 \\
\hline \multirow[t]{2}{*}{ Marital status: separated/divorced } & 7.16 & 7.13 & 7.31 \\
\hline & 2,006 & 1,673 & 333 \\
\hline \multirow[t]{2}{*}{ Marital status: married } & 7.36 & 7.38 & 7.34 \\
\hline & 26,461 & 10,082 & 16,379 \\
\hline \multirow[t]{2}{*}{ Children } & 7.34 & 7.37 & 7.32 \\
\hline & 13,728 & 5,568 & 8,160 \\
\hline \multirow[t]{2}{*}{ Illiterate } & 7.08 & 6.95 & 7.15 \\
\hline & 1,336 & 455 & 881 \\
\hline \multirow[t]{2}{*}{ Primary studies } & 7.20 & 7.18 & 7.22 \\
\hline & 6,661 & 2,215 & 4,446 \\
\hline \multirow[t]{2}{*}{ Secondary studies } & 7.25 & 7.28 & 7.23 \\
\hline & 8,230 & 3,074 & 5,156 \\
\hline \multirow[t]{2}{*}{ Graduation and vocational training } & 7.29 & 7.30 & 7.28 \\
\hline & 13,301 & 5,634 & 7,667 \\
\hline \multirow[t]{2}{*}{ University and post-university studies } & 7.45 & 7.42 & 7.47 \\
\hline & 9,879 & 5,274 & 4,605 \\
\hline \multicolumn{4}{|l|}{ Objective nature job characteristics } \\
\hline \multirow[t]{2}{*}{ Managerial post } & 7.80 & 7.74 & 7.83 \\
\hline & 2,787 & 756 & 2,031 \\
\hline \multirow[t]{2}{*}{ Intermediate post with subordinates } & 7.56 & 7.58 & 7.55 \\
\hline & 6,256 & 1,945 & 4,311 \\
\hline \multirow[t]{2}{*}{ Self-employed } & 7.15 & 7.15 & 7.15 \\
\hline & 4,271 & 1,469 & 2,802 \\
\hline \multirow[t]{2}{*}{ Employee } & 7.20 & 7.26 & 7.15 \\
\hline & 26,093 & 12,482 & 13,611 \\
\hline \multirow[t]{2}{*}{ Public sector workers } & 7.51 & 7.52 & 7.49 \\
\hline & 8,035 & 4,361 & 3,674 \\
\hline \multirow[t]{2}{*}{ Temporary job } & 6.98 & 7.08 & 6.88 \\
\hline & 7,330 & 3,557 & 3,773 \\
\hline
\end{tabular}


Table 1.continued

\begin{tabular}{lccc}
\hline \multirow{2}{*}{ Part-time job } & Total & Women & Men \\
\cline { 2 - 4 } Continuous day & 7.14 & 7.19 & 7.01 \\
& 5,210 & 3,760 & 1,450 \\
Sunday working days & 7.23 & 7.27 & 7.19 \\
& 20,879 & 10,408 & 10,471 \\
Working day $>40$ hours & 6.93 & 6.91 & 6.95 \\
& 2,576 & 1,168 & 1,408 \\
Labour agreement & 7.16 & 7.06 & 7.19 \\
& 11,091 & 2,918 & 8,173 \\
Wage $<600$ euros & 7.34 & 7.37 & 7.32 \\
& 14,100 & 6,220 & 7,880 \\
$600<$ Wage $<1200$ euros & 6.82 & 6.94 & 6.46 \\
& 3,242 & 2,489 & 753 \\
$1200<$ Wage $<2100$ euros & 7.05 & 7.18 & 6.88 \\
$2100<$ Wage $<3000$ euros & 10,727 & 5,985 & 4,742 \\
& 7.31 & 7.41 & 7.26 \\
$3000<$ Wage $<4500$ euros & 9,425 & 3,405 & 6,020 \\
Wage $>4500$ euros & 7.51 & 7.59 & 7.48 \\
& 10,512 & 3,155 & 7,357 \\
& 7.60 & 7.61 & 7.59 \\
& 5,190 & 1,572 & 3,618 \\
& 8.27 & 8.15 & 8.29 \\
& 311 & 46 & 265 \\
\hline
\end{tabular}

greater extent, to combine other personal and family aspects traditionally related to women. ${ }^{17}$

Regarding the working days, women endure both working on Sundays and longer than 40-hour working weeks to a higher extent than men. This result could be justified, in line with the work of Sloane - Williams (2000), arguing that those types of working days allow to combine family and personal obligations to a lesser extent.

Finally, there is a direct relationship between wages and satisfaction levels. It is worth noting that in all wage ranges women's satisfaction is higher than men's. Note, in any case, that the proportion of women decreases as the level of pay increases. In fact, the proportion of women with a wage lower than 600 Euros is $76.77 \%$ and with a wage higher than 4500 Euros is $14.79 \%$. These data do not correspond with those related to qualifications, since the proportion of women with university and post-university studies is higher than that of men (around $53.39 \%)$.

17 There is a clear predominance of women among part-time workers $(72.2 \%)$. 
Table 2 shows the marginal effects of the probit estimate of job satisfaction including the entire sample, women and $\operatorname{men}^{18}$. It can be seen that, supporting Clark's hypothesis (1997), women are more likely to be satisfied in their jobs in the highest job satisfaction category than their male colleagues $(6.7 \%)$, regardless of the inclusion of objective and subjective job characteristics, the personal ones and those associated with household chores.

Table 2. Ordered probit. Marginal effects (JS=2)

\begin{tabular}{lccc}
\hline & Total & Women & Men \\
\cline { 2 - 4 } Personal characteristics & & & \\
\hline Woman & & & \\
& & & \\
Age 30-40 years & $(0.000)$ & & \\
& -0.014 & -0.005 & -0.025 \\
Age 40-50 years & $(0.362)$ & $(0.926)$ & $(0.247)$ \\
& -0.028 & 0.019 & $-0.055^{*}$ \\
Age 50-60 years & $(0.076)$ & $(0.758)$ & $(0.011)$ \\
& -0.030 & 0.050 & $-0.063^{*}$ \\
Age $>$ 60 years & $(0.132)$ & $(0.537)$ & $(0.014)$ \\
Marital status: separated/divorced & 0.052 & 0.221 & 0.018 \\
& $(0.143)$ & $(0.214)$ & $(0.673)$ \\
Marital status: married (partner) & -0.003 & 0.011 & 0.005 \\
Children & $(0.950)$ & $(0.935)$ & $(0.946)$ \\
Primary studies & -0.002 & -0.004 & -0.009 \\
Secondary studies & $(0.911)$ & $(0.958)$ & $(0.726)$ \\
Baccalaureate and vocational training & -0.018 & 0.016 & $-0.031^{*}$ \\
University and post-university studies & $(0.085)$ & $(0.707)$ & $(0.018)$ \\
& -0.0003 & 0.086 & -0.020 \\
& $(0.989)$ & $(0.477)$ & $(0.523)$ \\
& 0.007 & 0.128 & -0.017 \\
& $(0.234)$ & $(0.853)$ & $(0.219)$ \\
\hline
\end{tabular}

18 Since the dependent variable has three categories, it is an ordered probit and the marginal effects are corresponding to the maximum values of job satisfaction. In the econometric estimates, the following have also been included and in accordance with the existing literature: type of job and region of the worker to measure its influence on satisfaction. In any case, since it moves away from the objective of this study, it is not published. One can refer to the author to request for the complete estimates. 
Table 2. continued

\begin{tabular}{|c|c|c|c|}
\hline & Total & Women & Men \\
\hline \multicolumn{4}{|l|}{ Objective nature job characteristics } \\
\hline \multirow[t]{2}{*}{ Manager } & $0,104 * * *$ & $0,504 * * *$ & $0,081 * * *$ \\
\hline & $(0,000)$ & $(0,000)$ & $(0,003)$ \\
\hline \multirow[t]{2}{*}{ Intermediate manager with subordinates } & $0,050 * * *$ & $0,126^{*}$ & 0,048 \\
\hline & $(0,000)$ & $(0,012)$ & $(0,000)$ \\
\hline \multirow[t]{2}{*}{ Self-employed } & 0,059 & $-0,011$ & 0,084 \\
\hline & $(0,156)$ & $(0,946)$ & $(0,114)$ \\
\hline \multirow[t]{2}{*}{ Public sector } & 0,031 & $0,088^{*}$ & $0,025 * *$ \\
\hline & $(0,004)$ & $(0,031)$ & $(0,086)$ \\
\hline \multirow[t]{2}{*}{ Temporary job } & $-0,001$ & $0,105^{*}$ & $-0,035$ \\
\hline & $(0,968)$ & $(0,022)$ & $(0,026)$ \\
\hline \multirow[t]{2}{*}{ Part-time job } & $-0,003$ & $-0,009$ & $-0,025$ \\
\hline & $(0,860)$ & $(0,858)$ & $(0,316)$ \\
\hline \multirow[t]{2}{*}{ Continuous day } & $-0,011$ & $-0,017$ & $-0,014$ \\
\hline & $(0,214)$ & $(0,642)$ & $(0,185)$ \\
\hline \multirow[t]{2}{*}{ Sunday working days } & 0,004 & 0,053 & $-0,005$ \\
\hline & $(0,867)$ & $(0,518)$ & $(0,863)$ \\
\hline \multirow[t]{2}{*}{ Working day $>40$ hours } & 0,008 & $-0,039$ & 0,009 \\
\hline & $(0,452)$ & $(0,472)$ & $(0,541)$ \\
\hline \multirow[t]{2}{*}{ Labour agreement } & 0,014 & 0,005 & 0,022 \\
\hline & $(0,077)$ & $(0,882)$ & $(0,032)$ \\
\hline \multirow[t]{2}{*}{ Number or hours worked } & $-0,056^{*}$ & $-0,161^{*}$ & $-0,20 *$ \\
\hline & $(0,014)$ & $(0,035)$ & $(0,565)$ \\
\hline \multirow[t]{2}{*}{$600<$ Wage $<1200$} & $0,047^{*}$ & $0,168 * *$ & $0,056^{*}$ \\
\hline & $(0,028)$ & $(0,007)$ & $(0,225)$ \\
\hline \multirow[t]{2}{*}{$1200<$ Wage $<2100$ euros } & $0,093 * * *$ & $0,246^{* * *}$ & $0,110 * * *$ \\
\hline & $(0,000)$ & $(0,001)$ & $(0,016)$ \\
\hline \multirow[t]{2}{*}{$2100<$ Wage $<3000$ euros } & $0,120 * * *$ & $0,343 * * *$ & $0,116^{* * *}$ \\
\hline & $(0,0000)$ & $(0,000)$ & $(0,012)$ \\
\hline \multirow[t]{2}{*}{$3000<$ Wage $<4500$ euros } & $0,109 * * *$ & $0,257 * *$ & $0,123 * * *$ \\
\hline & $(0,000)$ & $(0,004)$ & $(0,008)$ \\
\hline \multirow[t]{2}{*}{ Wage $>4500$ euros } & $0,251 * * *$ & $0,831 * *$ & $0,259 * * *$ \\
\hline & $(0,000)$ & $(0,006)$ & $(0,000)$ \\
\hline \multicolumn{4}{|l|}{ Subjective nature job characteristics } \\
\hline \multirow[t]{2}{*}{ Satisfaction with promotion $(0-10)$} & $0,146^{* * *}$ & $0,325 * * *$ & $0,158 * * *$ \\
\hline & $(0,000)$ & $(0,000)$ & $(0,000)$ \\
\hline \multirow[t]{2}{*}{ Satisfaction with job stability $(0-10)$} & $0,169 * * *$ & $0,427 * * *$ & $0,174 * * *$ \\
\hline & $(0,000)$ & $(0,000)$ & $(0,000)$ \\
\hline \multirow{2}{*}{$\begin{array}{l}\text { Satisfaction with personal development } \\
(0-10)\end{array}$} & & & \\
\hline & $(0,000)$ & $\begin{array}{l}0,940 \\
(0,000)\end{array}$ & $(0,000)$ \\
\hline
\end{tabular}


Table 2. continued

\begin{tabular}{lccc}
\hline & Total & Women & Men \\
\cline { 2 - 4 } Satisfaction with senior levels (0-10) & $0,206^{* * *}$ & $0,528^{* * *}$ & $0,203^{* * *}$ \\
Satisfaction with labour relations $(0-10)$ & $(0,000)$ & $(0,000)$ & $(0,000)$ \\
Satisfaction with timetable & $0,123^{* * *}$ & $0,272^{* *}$ & $0,136^{* * *}$ \\
& $(0,000)$ & $(0,002)$ & $(0,000)$ \\
Satisfaction with flexibility & $0,177^{* * *}$ & $0,390^{* * *}$ & $0,193^{* * *}$ \\
& $(0,000)$ & $(0,000)$ & $(0,000)$ \\
Stress & $0,126^{* * *}$ & $0,158^{* * *}$ & $0,107^{* * *}$ \\
& $(0,000)$ & $(0,000)$ & $(0,000)$ \\
Physical effort & $-0,113^{* * *}$ & $-0,299^{* * *}$ & $-0,110^{* * *}$ \\
& $(0,000)$ & $(0,000)$ & $(0,000)$ \\
Security at work & $-0,034^{* * *}$ & $-0,082^{*}$ & $-0,038^{* * *}$ \\
Over-education & $(0,000)$ & $(0,022)$ & $(0,001)$ \\
& $0,188^{* * *}$ & $0,421^{* * *}$ & $0,202^{* * *}$ \\
Under-education & $(0,000)$ & $(0,000)$ & $(0,000)$ \\
& $-0,126^{* * *}$ & $-0,118$ & $-0,131^{* * *}$ \\
Household conditions & $(0,000)$ & $(0,000)$ & $(0,000)$ \\
\hline Hours used in housework & $-0,014$ & $-0,135^{* * *}$ & 0,042 \\
Satisfaction with partner housework hours & $-0,621$ & $(0,000)$ & $(0,204)$ \\
& & & \\
\hline
\end{tabular}

Notes: * Significant at $10 \% ; * *$ Significant at $5 \% ; * * *$ Significant at $1 \%$ level.

Other control variables included are occupation, region and year.

With regard to the personal characteristics, in the case of men, an inverted "U" in the age variable is observed, being the age range of 40-60 years the least satisfied. At the same time, men with children show a $3.1 \%$ probability of being in the highest job satisfaction category that is below average, while this factor is not significant for women. It is noteworthy that the level of education does not seem to affect satisfaction either for men or for women. It must not be forgotten that this variable is highly correlated in many cases with the types of job and wages, so there could be co-linearity problems ${ }^{19}$.

19 They have remained, in any case, because the objective of the study is to focus on the differences according to gender and not so much on the rest of the variables. 
Objective job characteristics have a greater influence on job satisfaction than the personal ones ${ }^{20}$. We have pointed out in the descriptive study that having a managerial or intermediate post with subordinates increases the probability of being satisfied at work, and this is especially true for women. If a glass ceiling that prevents their access to the positions of greater responsibility ${ }^{21}$ is considered, holding such positions could affect satisfaction to a greater extent. Meanwhile, working in the public sector affects satisfaction positively and it is also women who are more likely to be more satisfied in such higher position $(8.8 \%$ versus $2.5 \%$ ). This fact can be justified by better conditions offered by the state to reconcile work and personal life. Combining this explanation with the above, there may be a group of women who choose to focus on their professional life and would experience greater satisfaction when accessing managerial posts and there would be another group that would experience it in their personal life and would appreciate their work flexibility to a greater extent.

The number of working hours has a negative influence on the satisfaction level, both in the case of women and men.

As the wage increases, so does the probability of being satisfied at work. Again, the impact on women is considerably higher in all ranges compared to men. If a wage gap based on sex is considered, which as shown by the data does not correspond to the educational level, it would be logical to think that reaching a higher wage level has a greater impact on satisfaction levels.

Subjective job characteristics have a greater influence on satisfaction. Satisfaction with promotion, stability, personal development, senior levels, labour relations, working hours, flexibility of hours and safety at work have a positive and significant influence on satisfaction levels and, again, the impact on women is higher than on men. This does not apply to the level of stress and physical effort, despite being negatively evaluated by both, men and women, it seems to impact women more negatively. These results support the idea of Sloane - Williams (2000) and provide some evidence of women preferring jobs with more flexibility and stability, personal development and favourable labour relations.

With regard to the educational labour imbalances, it is observed that they also affect satisfaction, but with a different pattern depending on $\operatorname{sex}^{22}$. Having a high-

20 Estimations have been built up progressively including: i) the personal characteristics; (ii) personal and objective job characteristics; iii) personal and subjective job characteristics. The coefficient linked to the female variable is in all cases positive and significant. Robustness of estimates is thus demonstrated.

21 The proportion of female managers in the sample is just $27.13 \%$ and workers with wages higher than 4500 euros constitute $14.79 \%$.

22 See Sánchez-Sánchez - Fernández (2015) for a more comprehensive study of the influence of these variables on satisfaction. 
er educational level than required for the job has a negative influence in the case of men, while for women, it is having lower qualification than required which has a higher negative impact. Finally, the number of hours spent on housework does not influence satisfaction levels, whereas the fact that the partner shares the housework does to a certain extent.

In Table 3, age groups (under 30, 30-40, 40-50, 50-60 and over 60 years) are separated to see if the variable associated with female continues to have a significant effect on satisfaction in all ranges ${ }^{23}$. In this sense, women's job prospects should have changed as the rate of activity increased and was put at the same level as men's working conditions ${ }^{24}$. The objective would, therefore, be to reduce the self-selection bias, since, as has already been pointed out, women's participation in the labor market is matched to men, when younger population is considered ${ }^{25}$.

Table 3. Ordered probit. Marginal effects (JS=2)

\begin{tabular}{cccccc}
\hline & $<30$ years & $30-40$ years & $40-50$ years & $50-60$ years & $>60$ years \\
\hline Women & $0.079^{*}$ & $0.044^{*}$ & $0.082^{* * *}$ & $0.078^{* *}$ & -0.036 \\
& $(0.020)$ & $(0.016)$ & $(0.000)$ & $(0.002)$ & $(0.638)$ \\
\hline
\end{tabular}

Notes: * Significant at 10\%; ** Significant at 5\%; ***Significant at $1 \%$ level.

It can be seen that, except in the last age group that is not significant, the variable associated with being a woman increases the probability of being satisfied in the job. Therefore, it cannot be confirmed that for younger people satisfaction levels are the same for both sexes. In any case, it is true that the associated coefficient for young people between 30 and 40 years of age is almost half of the rest of the age groups (except for those over 60) and its significance level is lower than the 40-50 and 50-60 age groups.

Since the group of women aged 30-40 years has higher qualification levels, this result would support the hypothesis suggested by Clark (1997), and later confirmed by Green et al. (2016), that the differences in job satisfaction are tran-

23. In Appendix 2 the influence of all the variables included in the analysis on each of the age groups is observed.

24 As mentioned before, the differences in female and men activity rates in younger population are very small. Therefore, self-selection bias should have been reduced.

25 A formal evaluation of the self-selection bias could be solved econometrically with Heckman (1979) correction. However, data from SLQW do not allow for this procedure, since information is not available for people who are not in the labour market. The European Social Survey would have been an alternative but the number of surveyed people per country is very small (between 800 and 1500). The analysis made by age and educational level would not be viable, as the number of observations is small. 
sitional. In the group aged between 20 and 30 years, where differences should disappear to a greater extent, the significance level is lower, although the probability of being satisfied is higher. Therefore, it cannot be stated with one hundred per cent certainty that the paradox of female satisfaction disappears as age decreases. The characteristics intrinsic to our labour market, such as discrimination, prevent equality of job satisfaction among younger people. Studies by Clark (1997) and Green et al. (2016) found that labour characteristics are more equalised in the UK. ${ }^{26}$

Finally, in Table 4 the sample is divided into workers who have no studies or have primary studies, those who have secondary school or vocational training studies and those who have university or post-university education. ${ }^{27}$ The objective is similar to that of the previous estimates. As noted before, women's activity rates at higher educational levels are much higher than those at the lower levels. Moreover, in some cases, they are superior to those of men. The results show that women with higher studies are more likely to be more satisfied than men, while this is not the case for those who have basic education (primary). In the case of secondary education or vocational training, the probability for a woman to be more satisfied in the highest job satisfaction category is $7.2 \%$ and $6.8 \%$ for those with university studies. This result again contrasts with the hypothesis by Clark (1997) and Donohue - Heywood (2004), who claimed that in higher levels of education the satisfaction levels between men and women should be at the same level.

Table 4. Ordered probit. Marginal effects (JS=2)

\begin{tabular}{lccc}
\hline & Primary studies & Secondary studies & $\begin{array}{c}\text { University and post- } \\
\text { university studies }\end{array}$ \\
\hline Women & 0.046 & $0.072^{* * *}$ & $0.068^{* * *}$ \\
& 0.099 & 0.000 & 0.000 \\
\hline
\end{tabular}

Note: * Significant at 10\%; ** Significant at 5\%; *** Significant at $1 \%$ level.

26 The behaviour of the UK labour market is less discriminating against women than the Spanish one, judging from the unadjusted gender pay gap figures that Eurostat provides. The unadjusted gender pay gap is calculated as the difference between the average gross hourly earnings of male and female employees as a percentage of average gross hourly earnings of male paid employees. In 2014, for workers aged between 25 and 34, in the UK that figure stands at $5 \%$ compared to $10.5 \%$ in the Spanish case, and for older workers $(+65)$ in the UK it is about $25.7 \%$ compared to $50 \%$ in Spain.

27 In Appendix 3, the influence of all the variables included in the analysis on each groups of educational level is observed. 
Table 5. Non-linear decomposition of job satisfaction: female - male

\begin{tabular}{lcccc}
\hline & Total & Age $40-50$ & Sec. Studies & Univ. Studies \\
$\Omega=1$ & 0.0118 & 0.0682 & 0.0374 & -0.0520 \\
Characteristics & -0.1265 & -0.1509 & -0.2608 & -0.1821 \\
Coefficient (Returns) & 0.1383 & 0.2191 & 0.2982 & 0.1301 \\
$\Omega=0$ & & & & \\
Characteristics & 0.5336 & 0.3972 & 1.0860 & 1.1591 \\
Coefficient (Returns) & -0.5218 & -0.3290 & -1.0486 & -1.2111 \\
\hline
\end{tabular}

In Table 5 the Oaxaca-Blinder methodology developed in equation (4) to decompose the observed differences in job satisfaction between women and men in two components is shown: the component corresponding to job characteristics, both objective and subjective, and the performance obtained from them ${ }^{28}$.

Two different results are shown. The one where $\Omega$ is equal to an identity matrix where the coefficients estimated would be the ones for women (characteristics of the job and returns of these characteristics) and the one where $\Omega$ is a null matrix, the coefficients would be the ones of men.

Firstly, the entire sample has been considered, and then the group of women aged between 40 and 50 years and the corresponding secondary school and university educational level, where there is a greater difference in satisfaction between men and women with a greater significance level, is considered.

It can be observed that if the whole sample is considered, the difference in satisfaction of women compared to men is just $0.0118^{29}$. From the perspective of women ( $\Omega$ is equal to an identity matrix), the positive sign is explained by the evaluation made by women about their job characteristics, which, in fact, is higher than men's (0.1383). However, the characteristics of the job they occupy reduce their total satisfaction $(-0.1265)$. The results prove that the performance in terms of satisfaction obtained by women in their jobs is large enough to compensate the worse characteristics of their jobs.

If the analysis is focused on the age group of 40-50 years the results are similar, although the differences in satisfaction of women compared to men are higher (0.0682). Again, their job characteristics reduce their satisfaction $(-0.1509)$, however, the evaluation of various labour conditions is higher (0.2191).

Finally, the results in the group corresponding to workers with secondary school and university studies are in the same line. However, it calls our attention that job characteristics reduce the satisfaction of women with higher educational levels $(-0.1821$ in university and post-university studies and -0.2608 in

28 The decomposition of Oaxaca-Blinder is estimated following Sinning et al. (2008).

29 Job satisfaction differences are obtained in terms of conditional expectations. 
secondary school studies) to a greater extent than in total $(-0.1265)$. This result could be justified by the disparity between the proportion of women with higher educational levels, which is much higher than that corresponding to higher wage levels.

The results when $\Omega$ is equal to a null matrix are analogous. In all cases, men's job characteristics increase their total job satisfaction, although the returns they get from them reduce it. In this case, it is men with secondary and university studies that penalise their work circumstances to a greater extent.

\section{CONCLUSIONS}

Our research examines the paradox between high relative levels of job satisfaction and the characteristics of women's jobs compared to men's. In order to do it, the Survey of Quality of Life at Work is used between the years of 2006-2010 and the differences in satisfaction levels are studied, as well as the influence of personal and job characteristics, both objective and subjective, on satisfaction. Then the sample is divided, firstly, by age group and, secondly, by educational levels to see whether differences in satisfaction by sex predominate, when selfselection bias is reduced.

The study shows that in the Spanish case, although the working conditions of women are worse than those of their male colleagues (at least in terms of the wages and level of responsibility in their jobs), the former are more likely to be satisfied at work than the latter. This paradox persists regardless of the age group under consideration. The significance level, in any case, is higher for women between 40 and 50 years of age and those between 50 and 60 years, which could support, at least partially, the hypothesis that the prospects and selection bias of women decreases as age does.

Satisfaction levels of women are higher than those of men in all age groups except for the over 60 years' age group, where no significant differences are observed. In any case, the probability that a woman is satisfied is lower in the age group corresponding to 30-40 years, which may indeed be an indication that women's prospects, although they are still lower than men's, are improving slightly in the new generations. The fact that this result is observed in this age group and not in lower age groups is apparently a contradiction. The higher unemployment rate among younger people (around 32\%) could be distorting the prospects of younger people.

Regarding educational levels, women are more likely to be satisfied than their male colleagues, except for those whose educational level is lower than primary 
education, where the variable is not significant. Again, the results do not support the hypothesis that satisfaction levels converge as the level of education increases.

The factors affecting satisfaction levels are diverse. So, having children has a negative influence on men's job satisfaction, but not in the case of women. It is also noted that the fact of having a managerial or intermediate post with subordinates and wage levels have a positive effect on satisfaction levels, and it is precisely women who give more importance to these types of variables. The influence of subjective job characteristics also has a greater impact on women than on men.

Returning to the hypotheses proposed in the introduction, the reduction in the differences in women's and men's job satisfaction among the younger population and higher levels of education is not observed. In the younger age group and in the corresponding group of more qualified people, the likelihood that women are more satisfied remains higher than that of men. Differences in job satisfaction do not appear to be attributable to self-selection bias as the activity rates of younger women are similar to that of males and in the population stratum with higher levels of study are, in fact, higher. For the older population with lower level of education it is feasible that women with lower probability of finding a job are not participating in the labour market.

Regarding the hypothesis of lower job prospects, the data show that the Spanish women are less present in the positions requiring greater responsibility (managers and those that have workers under their supervision) and those with higher wages, so it is likely that their prospects will be lower. In addition, the OaxacaBlinder decomposition suggests that these expectations are actually influencing the differences in job satisfaction. However, it is not proven that these expectations disappear as age decreases or the educational level increases.

Concerning the third hypothesis, the results point out that women would choose jobs with different characteristics than those chosen by men (flexibility, stability, labour environment and personal development). The omission of this kind of variables in the analysis will overestimate female job satisfaction coefficient. In any case, the inclusions of these variables do not completely eliminate the differences in job satisfaction between men and women.

The probable existence of a "glass ceiling", that prevents women, regardless of age or educational level, from having access to posts of greater responsibility and wage, could cause that women who actually reach these posts will be more satisfied than their male colleagues, who have not had such difficulties. As the labour market and society become more equal in terms of roles, discrimination and activities performed by men and women, it will be possible that the paradox of female job satisfaction becomes diluted. 
The prevalence of these differences encourages, in any case, to continue examining the causes. In this sense, it would be interesting to corroborate the existence of discrimination in recruiting and working conditions of women compared to men and the effects arising from job satisfaction.

\section{REFERENCES}

Álvarez, G. (2004): Análisis empírico de los determinantes de la satisfacción laboral en España (An Empirical Analysis of Job Satisfaction in Spain). Revista de Economía y Empresa, 52: 105-118.

Bender, K. A. - Donohue, S. - Heywood, J. S. (2005): Job Satisfaction and Gender Segregation. Oxford Economic Papers, 57(3): 479-496.

Bender, K. A. - Heywood, J. S. (2006): Job Satisfaction of the Highly Educated: The Role of Gender, Academic Tenure and Earnings. Scottish Journal of Political Economy, 53(2): 253-279.

Borra, C. - Gómez, F. - Salas, M. (2007): Los determinantes de la satisfacción laboral de los economistas: evidencia a partir de una nueva muestra (The Determinants of Job Satisfaction of Economists: Evidence from a New Sample). Economic Working Papers, No. E2007/02, Centro de Estudios Andaluces.

Carleton, C. J. - Clain, S. H. (2012): Women, Men, and Job Satisfaction. Eastern Economic Journal, 38(Summer): 331-355.

Clark, A. E (1997): Job Satisfaction and Gender: Why Are Women So Happy at Work? Labour Economics, 4(4): 341-372.

Clark, A. E. - Oswald, A. J. (1996): Satisfaction and Comparison Income. Journal of Public Economics, 61: 359-381.

Donohue, S. M. - Heywood, J. S. (2004): Job Satisfaction and Gender: An Expanded Specification from the NLSY. International Journal of Manpower, 25(2): 211-234.

Green, C. - Heywood, J. - Kler, P. - Leeves, G. (2016): Paradox Lost: Disappearing Female Job Satisfaction. Working Paper, No. 002, Lancaster University Management School.

Hauret, L. - Williams, D. R. (2017): Cross-National Analysis of Gender Differences in Job Satisfaction. Industrial Relations, 56(2): 203-235

Kaiser, L. C. (2007): Gender-Job Satisfaction Differences across Europe. International Journal of Manpower, 28(1): 75-94.

Kifle, T. - Kler, P. - Shankar, S. (2014): Are Women Really that Happy at Work? Australian Evidence on the Contented Female. Applied Economics, 46(7): 686-697.

Long, J. E. (2005): The Effects of Tastes and Motivation on Individual Income. Industrial and Labor Relations, 48(2): 338-351.

Mora, T. - Ferrer-I-Carbonell, A. (2009): The Job Satisfaction Gender Gap among Young Recent Universities Graduates: Evidence for Catalonia. The Journal of Social-Economics, 38: 581589.

Oaxaca, R. (1973): Male-Female Wage Differentials in Urban Labour Markets. International Economic Review, 4(3): 693-709.

Oaxaca, R. L. - Ransom, M. (1994): On Discrimination and the Decomposition of Wage Differentials. Journal of Econometrics, 61(1): 5-21

Rico Belda, P. (2012): Satisfacción Laboral De Los Asalariados En España (Job Satisfaction of Employees in Spain). Revista De Métodos Cuantitativos Para La Economía Y La Empresa, 14: $137-158$. 
Sánchez-Sánchez, N. - Fernández, A. C. (2015): Desajuste Educacional Y De Competencias: Efectos Diferenciales Sobre La Satisfacción Laboral. Un Estudio Aplicado Al Mercado De Trabajo Español (Educational and Skill Mismatches: Differential Effects on Job Satisfaction. A Study Applied to the Spanish Job Market). Estudios De Economía, 41(2): 261-281.

Sinning, M. - Markus, H. - Bauer, T. K. (2008): The Blinder-Oaxaca Decomposition for NonLinear Regression Models. The Stata Journal, 8(4): 480-492.

Sloane, P. J. - Ward, M. E. (2001): Cohort Effects and Job Satisfaction of Academics. Applied Economics Letters, 8(12): 787-791.

Sloane, P. J. - Williams, H. (2000): Job Satisfaction, Comparison Earnings and Gender. Labour, 14(3): 473-501.

Sousa-Poza, A. - Sousa-Poza, A. A. (2000a): Taking Another Look at the Gender/Job Satisfaction Paradox. Kyklos, 53(2): 135-52.

Sousa-Poza, A. - Sousa-Poza, A. A. (2000b): Well-Being at Work: A Cross National Analysis of the Levels and Determinants of Job Satisfaction. Journal of Socio-Economics, 29(6): 517-538.

Sousa-Poza, A. - Sousa-Poza, A. A. (2003): Gender Differences in Job Satisfaction in Great Britain, 1991-2000: Permanent or Transitory? Applied Economics Letters, 10(11): 691-694.

Souza-Poza, A. - Sousa-Poza, A. A. (2007): The Effect of Job Satisfaction on Labour Turnover by Gender: An Analysis for Switzerland. The Journal of Socio-Economics, 36(6): 895-913.

Verhofstadt, E. - De Witte, H. - Omey, E. (2007): Higher Educated Workers: Better Jobs But Less Satisfied? International Journal of Manpower, 28(2): 135 - 151 


\section{APPENDIX 1}

\section{Definition of control variable}

\begin{tabular}{|c|c|c|c|c|}
\hline & Definition & Measure & Mean & $\begin{array}{l}\text { Standard } \\
\text { deviation }\end{array}$ \\
\hline \multicolumn{5}{|l|}{ Personal characteristics } \\
\hline Female & If the individual is female & $0 / 1$ & .384 & .486 \\
\hline Age $<30$ year & Age $<30$ years & $0 / 1$ & .096 & .294 \\
\hline Age $30-40$ year & $40>$ Age $>=30$ years & $0 / 1$ & .328 & .469 \\
\hline Age $40-50$ year & $50>$ Age $>=40$ years & $0 / 1$ & .370 & .483 \\
\hline Age $50-60$ year & $60>$ Age $>=50$ years & $0 / 1$ & .186 & .389 \\
\hline Age $>60$ year & Age $>=60$ & $0 / 1$ & .021 & .143 \\
\hline Single & If the individual is single & $0 / 1$ & .012 & .108 \\
\hline Divorced & If the individual is divorced & $0 / 1$ & .916 & .277 \\
\hline Partner & $\begin{array}{l}\text { If the individual is married or } \\
\text { cohabiting }\end{array}$ & $0 / 1$ & .006 & .079 \\
\hline Children & If the individual has children & $0 / 1$ & .581 & .493 \\
\hline \multicolumn{5}{|l|}{ Education } \\
\hline No education & No education & $0 / 1$ & .029 & .168 \\
\hline Primary school & $\begin{array}{l}\text { Maximum education level } \\
\text { of primary }\end{array}$ & $0 / 1$ & .164 & .371 \\
\hline Secondary school & $\begin{array}{l}\text { Maximum education level } \\
\text { of secondary }\end{array}$ & $0 / 1$ & .205 & .404 \\
\hline High-school & $\begin{array}{l}\text { Maximum education level } \\
\text { of high-school }\end{array}$ & $0 / 1$ & .339 & .473 \\
\hline University & $\begin{array}{l}\text { Maximum education level of } \\
\text { University }\end{array}$ & $0 / 1$ & .263 & .440 \\
\hline \multicolumn{5}{|l|}{ Job characteristics } \\
\hline Manager & If individual is manager & $0 / 1$ & .040 & .196 \\
\hline Intermediate manager & $\begin{array}{l}\text { If individual has an intermedi- } \\
\text { ate job }\end{array}$ & $0 / 1$ & .209 & .407 \\
\hline Self-employed & If individual is self-employed & $0 / 1$ & .011 & .104 \\
\hline Public sector & $\begin{array}{l}\text { If individual works in public } \\
\text { sector }\end{array}$ & $0 / 1$ & .253 & .435 \\
\hline Temporal worker & $\begin{array}{l}\text { If individual holds temporal } \\
\text { contract }\end{array}$ & $0 / 1$ & .187 & .390 \\
\hline Part-time worker & $\begin{array}{l}\text { If individual holds part-time } \\
\text { job }\end{array}$ & $0 / 1$ & .121 & .326 \\
\hline Continuous working & $\begin{array}{l}\text { If individual works with a } \\
\text { continuous timetable }\end{array}$ & $0 / 1$ & .576 & .494 \\
\hline Sunday & $\begin{array}{l}\text { If individual works on Sunday } \\
\text { or night }\end{array}$ & $0 / 1$ & .037 & .190 \\
\hline More than 40 hours & $\begin{array}{l}\text { If individual works more than } \\
40 \text { hours per week }\end{array}$ & $0 / 1$ & .242 & .428 \\
\hline
\end{tabular}


Appendix 1 cont.

\begin{tabular}{llccc}
\hline & \multicolumn{1}{c}{ Definition } & Measure & Mean & $\begin{array}{c}\text { Standard } \\
\text { deviation }\end{array}$ \\
\hline Union agreement & $\begin{array}{l}\text { If the company has an union } \\
\text { agreement }\end{array}$ & $0 / 1$ & .407 & .491 \\
Hours & Number of hours worked & Ln(Hours) & 3.643 & .281 \\
Wages $<600$ & Net wages & $0 / 1$ & .059 & .236 \\
$600<=$ Wages $<1200$ & Net wages & $0 / 1$ & .268 & .443 \\
$1200<=$ Wages $<2100$ & Net wages & $0 / 1$ & .254 & .436 \\
$2100<=$ Wages $<3000$ & Net wages & $0 / 1$ & .273 & .445 \\
$3000<=$ Wages $<4500$ & Net wages & $0 / 1$ & .139 & .345 \\
Wages $>4500$ & Net wages & $0 / 1$ & .008 & .089
\end{tabular}

Subjective job characteristics

\begin{tabular}{|c|c|c|c|c|}
\hline Satisfaction with promotion & $\begin{array}{l}0 \text { if individual has satisfaction } \\
\text { between } 0 \text { to } 4,1 \text { if individual } \\
\text { has satisfaction higher than } 4\end{array}$ & $0 / 1$ & .650 & .476 \\
\hline Satisfaction with job stability & The same as the above & $0 / 1$ & .897 & .304 \\
\hline $\begin{array}{l}\text { Satisfaction with personal } \\
\text { development }\end{array}$ & The same as the above & $0 / 1$ & .929 & .257 \\
\hline Satisfaction with boss & The same as the above & $0 / 1$ & .883 & .322 \\
\hline $\begin{array}{l}\text { Satisfaction with labor rela- } \\
\text { tions }\end{array}$ & The same as the above & $0 / 1$ & .964 & .186 \\
\hline Satisfaction with timetable & The same as the above & $0 / 1$ & .880 & .325 \\
\hline Satisfaction with flexibility & The same as the above & $0 / 1$ & .783 & .413 \\
\hline Stress & The same as the above & $0 / 1$ & .729 & .444 \\
\hline Effort at work & The same as the above & $0 / 1$ & .551 & .497 \\
\hline Security at work & The same as the above & $0 / 1$ & .914 & .281 \\
\hline Over-education & $\begin{array}{l}\text { Higher level of education than } \\
\text { required }\end{array}$ & $0 / 1$ & .173 & .378 \\
\hline $\begin{array}{l}\text { Under-education } \\
\text { Household conditions }\end{array}$ & $\begin{array}{l}\text { Lower level of education than } \\
\text { required }\end{array}$ & $0 / 1$ & .021 & .142 \\
\hline Hours used in housework & $\begin{array}{l}\text { If individual used } 1 \text { or more } \\
\text { hours in housework }\end{array}$ & $0 / 1$ & .759 & .428 \\
\hline $\begin{array}{l}\text { Satisfaction with partner } \\
\text { housework hours }\end{array}$ & $\begin{array}{l}0 \text { if individual has satisfaction } \\
\text { between } 0 \text { to } 7,1 \text { if individual } \\
\text { has satisfaction higher than } 7\end{array}$ & $0 / 1$ & .517 & .500 \\
\hline
\end{tabular}

Note: Regions and occupations are omitted due to lack of space. 


\section{APPENDIX 2}

Ordered probit. Marginal effects (JS=2)

\begin{tabular}{|c|c|c|c|c|c|}
\hline & $\begin{array}{c}<30 \\
\text { years }\end{array}$ & $\begin{array}{l}30-40 \\
\text { years }\end{array}$ & $\begin{array}{l}40-50 \\
\text { years }\end{array}$ & $\begin{array}{l}50-60 \\
\text { years }\end{array}$ & $\begin{array}{l}>60 \\
\text { years }\end{array}$ \\
\hline \multicolumn{6}{|l|}{ Personal characteristics } \\
\hline Female & $\begin{array}{c}0.079^{*} \\
(0.020)\end{array}$ & $\begin{array}{c}0.044^{*} \\
(0.016)\end{array}$ & $\begin{array}{l}0.082 * * * \\
(0.000)\end{array}$ & $\begin{array}{l}0.078 * * \\
(0.002)\end{array}$ & $\begin{array}{l}-0.036 \\
(0.638)\end{array}$ \\
\hline $\begin{array}{l}\text { Marital status: separated/ } \\
\text { divorced }\end{array}$ & $\begin{array}{c}-0.186 \\
(0.258)\end{array}$ & $\begin{array}{c}0.042 \\
(0.656)\end{array}$ & $\begin{array}{l}-0.088 \\
(0.186)\end{array}$ & $\begin{array}{l}0194^{*} \\
\quad(0.022)\end{array}$ & $\begin{array}{l}0.250^{* *} \\
(0.000)\end{array}$ \\
\hline $\begin{array}{l}\text { Marital status: married } \\
\text { (partner) }\end{array}$ & $\begin{array}{l}-0.087 \\
(0.035)\end{array}$ & $\begin{array}{l}-0.017 \\
(0.653)\end{array}$ & $\begin{array}{c}0.031 \\
(0.454)\end{array}$ & $\begin{array}{c}0.009 \\
(0.880)\end{array}$ & $\begin{array}{c}0.411 * \\
(0.016)\end{array}$ \\
\hline Children & $\begin{array}{c}0.060 \\
(0.151)\end{array}$ & $\begin{array}{l}-0.014 \\
(0.586)\end{array}$ & $\begin{array}{l}-0.021 \\
(0.137)\end{array}$ & $\begin{array}{l}-0.031 \\
(0.237)\end{array}$ & $\begin{array}{l}-0.244 \\
(0.121)\end{array}$ \\
\hline Primary studies & $\begin{array}{c}0.047 \\
(0.596)\end{array}$ & $\begin{array}{l}-0.091 \\
(0.108)\end{array}$ & $\begin{array}{l}-0.029 \\
(0.517)\end{array}$ & $\begin{array}{c}0.052 \\
(0.239)\end{array}$ & $\begin{array}{l}-0.026 \\
(0.785)\end{array}$ \\
\hline Secondary studies & $\begin{array}{c}0.131 \\
(0.120)\end{array}$ & $\begin{array}{l}-0.088 \\
(0.116)\end{array}$ & $\begin{array}{l}-0.022 \\
(0.624)\end{array}$ & $\begin{array}{c}0.052 \\
(0.239)\end{array}$ & $\begin{array}{l}-0.137 \\
(0.223)\end{array}$ \\
\hline $\begin{array}{l}\text { Baccalaureate and } \\
\text { vocational training }\end{array}$ & $\begin{array}{c}0.133 \\
(0.114)\end{array}$ & $\begin{array}{c}-0.139 * \\
(0.012)\end{array}$ & $\begin{array}{l}-0.046 \\
(0.306)\end{array}$ & $\begin{array}{c}0.060 \\
(0.205)\end{array}$ & $\begin{array}{c}0.098 \\
(0.313)\end{array}$ \\
\hline $\begin{array}{l}\text { University and post- } \\
\text { university studies }\end{array}$ & $\begin{array}{c}0.093 \\
(0.313)\end{array}$ & $\begin{array}{l}-0.115 \\
(0.051)\end{array}$ & $\begin{array}{l}-0.076 \\
(0.118)\end{array}$ & $\begin{array}{c}0.004 \\
(0.948)\end{array}$ & $\begin{array}{l}-0.097 \\
(0.492)\end{array}$ \\
\hline \multicolumn{6}{|c|}{ Objective nature job characteristics } \\
\hline Manager & $\begin{array}{c}0.298^{*} \\
(0.006)\end{array}$ & $\begin{array}{l}0.133 * * \\
(0.003)\end{array}$ & $\begin{array}{c}0.037 \\
(0.326)\end{array}$ & $\begin{array}{l}0.138 * * \\
(0.003)\end{array}$ & $\begin{array}{c}0.073 \\
(0.463)\end{array}$ \\
\hline $\begin{array}{l}\text { Intermediate manager } \\
\text { with subordinates }\end{array}$ & $\begin{array}{c}0.112 * \\
(0.011)\end{array}$ & $\begin{array}{c}0.036 \\
(0.059)\end{array}$ & $\begin{array}{r}0.035^{*} \\
(0.041)\end{array}$ & $\begin{array}{l}0.085 * * * \\
(0.000)\end{array}$ & $\begin{array}{l}-0.025 \\
(0.746)\end{array}$ \\
\hline Self-employed & $\begin{array}{c}0.284 \\
(0.061)\end{array}$ & $\begin{array}{c}0.063 \\
(0.321)\end{array}$ & $\begin{array}{c}0.066 \\
(0.322)\end{array}$ & $\begin{array}{c}0.067 \\
(0.483)\end{array}$ & $\begin{array}{c}-0.502 \\
(0.078)\end{array}$ \\
\hline Public sector & $\begin{array}{c}0.083 \\
(0.059)\end{array}$ & $\begin{array}{c}0.051 * \\
(0.010)\end{array}$ & $\begin{array}{c}0.026 \\
(0.132)\end{array}$ & $\begin{array}{c}0.011 \\
(0.653)\end{array}$ & $\begin{array}{c}0.013 \\
(0.837)\end{array}$ \\
\hline Temporary job & $\begin{array}{c}0.010 \\
(0.749)\end{array}$ & $\begin{array}{c}-0.038 \\
(0.052)\end{array}$ & $\begin{array}{c}0.019 \\
(0.364)\end{array}$ & $\begin{array}{c}0.031 \\
(0.367)\end{array}$ & $\begin{array}{c}-0.004 \\
(0.965)\end{array}$ \\
\hline Part-time job & $\begin{array}{c}-0.022 \\
(0.632)\end{array}$ & $\begin{array}{c}0.0192 \\
(0.444)\end{array}$ & $\begin{array}{c}0.022 \\
(0.426)\end{array}$ & $\begin{array}{c}-0.103^{*} \\
(0.017)\end{array}$ & $\begin{array}{c}-0.163 \\
(0.262)\end{array}$ \\
\hline Continuous day & $\begin{array}{c}0.011 \\
(0.693)\end{array}$ & $\begin{array}{c}0.026 \\
(0.080)\end{array}$ & $\begin{array}{c}-0.030^{*} \\
(0.033)\end{array}$ & $\begin{array}{l}-0.059 * * \\
(0.004)\end{array}$ & $\begin{array}{c}-0.016 \\
(0.777)\end{array}$ \\
\hline Sunday working days & -0.084 & -0.21 & -0.009 & $0.146^{* *}$ & 0.131 \\
\hline
\end{tabular}


Appendix 2 cont.

\begin{tabular}{lccccc}
\hline & $<30$ & $30-40$ & $40-50$ & $50-60$ & $>60$ \\
& years & years & years & years & years \\
\hline \multirow{3}{*}{ Working day $>$ 40 hours } & $(0.209)$ & $(0.555)$ & $(0.783)$ & $(0.006)$ & $(0.230)$ \\
& 0.013 & 0.023 & -0.021 & 0.023 & 0.119 \\
Labour agreement & $(0.707)$ & $(0.257)$ & $(0.250)$ & $(0.396)$ & $(0.067)$ \\
& 0.026 & 0.019 & -0.006 & $0.041^{*}$ & 0.029 \\
Number or hours worked & $(0.338)$ & $(0.184)$ & $(0.668)$ & $(0.027)$ & $(0.610)$ \\
& -0.041 & -0.068 & -0.025 & -0.081 & $-0.267^{*}$ \\
$600<$ Wage $<1200$ euros & $(0.472)$ & $(0.070)$ & $(0.539)$ & $(0.176)$ & $(0.037)$ \\
& 0.043 & 0.003 & 0.059 & 0.071 & $0.256^{*}$ \\
$1200<$ Wage $<2100$ euros & $(0.420)$ & $(0.926)$ & $(0.134)$ & $(0.244)$ & $(0.003)$ \\
& $0.138^{*}$ & 0.040 & $0.114^{* *}$ & 0.042 & $0.259^{*}$ \\
$2100<$ Wage $<3000$ euros & $(0.023)$ & $(0.290)$ & $(0.006)$ & $(0.501)$ & $(0.003)$ \\
& $0.231^{* * *}$ & $0.084^{*}$ & $0.120^{* *}$ & 0.042 & 0.196 \\
$3000<$ Wage $<4500$ euros & $(0.000)$ & $(0.032)$ & $(0.004)$ & $(0.507)$ & $(0.054)$ \\
& 0.112 & $0.091^{*}$ & $0.117^{* *}$ & 0.058 & 0.172 \\
Wage $>$ 4500 euros & $(0.245)$ & $(0.030)$ & $(0.007)$ & $(0.375)$ & $(0.076)$ \\
& -0.277 & $0.361^{*}$ & $0.273^{* * *}$ & 0.149 & $0.258^{* *}$ \\
& $(0.088)$ & $(0.001)$ & $(0.000)$ & $(0.120)$ & $(0.000)$
\end{tabular}

Subjective nature job characteristics

\begin{tabular}{|c|c|c|c|c|c|}
\hline $\begin{array}{l}\text { Satisfaction with } \\
\text { promotion }(0-10)\end{array}$ & $\begin{array}{l}0.210 * * * \\
(0.000)\end{array}$ & $\begin{array}{l}0.149 * * * \\
(0.000)\end{array}$ & $\begin{array}{l}0.146^{* * *} \\
(0.000)\end{array}$ & $\begin{array}{l}0.130 * * * \\
(0.000)\end{array}$ & $\begin{array}{l}0.222 * * * \\
(0.000)\end{array}$ \\
\hline $\begin{array}{l}\text { Satisfaction with job } \\
\text { stability }(0-10)\end{array}$ & $\begin{array}{l}0.184^{* * *} \\
(0.000)\end{array}$ & $\begin{array}{l}0.141^{* * * *} \\
(0.000)\end{array}$ & $\begin{array}{l}0.186^{* * *} \\
(0.000)\end{array}$ & $\begin{array}{l}0.212 * * * \\
(0.000)\end{array}$ & $\begin{array}{l}0.434 * * * \\
(0.000)\end{array}$ \\
\hline $\begin{array}{l}\text { Satisfaction with personal } \\
\text { development }(0-10)\end{array}$ & $\begin{array}{l}0.263 * * * \\
(0.000)\end{array}$ & $\begin{array}{l}0.326^{* * * *} \\
(0.000)\end{array}$ & $\begin{array}{l}0.322 * * * \\
(0.000)\end{array}$ & $\begin{array}{l}0.348^{* * * *} \\
(0.000)\end{array}$ & $\begin{array}{c}0.218 \\
(0.241)\end{array}$ \\
\hline $\begin{array}{l}\text { Satisfaction with senior } \\
\text { levels }(0-10)\end{array}$ & $\begin{array}{l}0.225^{* * *} \\
(0.000)\end{array}$ & $\begin{array}{c}-0.022 * * * \\
(0.154)\end{array}$ & $\begin{array}{l}0.225^{* * *} \\
(0.000)\end{array}$ & $\begin{array}{l}0.151 * * * \\
(0.000)\end{array}$ & $\begin{array}{c}0.043 \\
(0.671)\end{array}$ \\
\hline $\begin{array}{l}\text { Satisfaction with labour } \\
\text { relations }(0-10)\end{array}$ & $\begin{array}{l}(0.089 \\
(0.216)\end{array}$ & $\begin{array}{l}\left(0.211^{* * *}\right. \\
(0.000)\end{array}$ & $\begin{array}{c}\left(0.158^{* * *}\right. \\
(0.000)\end{array}$ & $\begin{array}{l}(0.095 \\
(0.058)\end{array}$ & $\begin{array}{l}(0.110 \\
(0.419)\end{array}$ \\
\hline Satisfaction with timetable & $\begin{array}{l}0.189 * * * \\
(0.000)\end{array}$ & $\begin{array}{l}0.132^{* * *} \\
(0.000)\end{array}$ & $\begin{array}{l}0.188^{* * *} \\
(0.000)\end{array}$ & $\begin{array}{l}0.240 * * * \\
(0.000)\end{array}$ & $\begin{array}{c}0.097 \\
(0.495)\end{array}$ \\
\hline Satisfaction with flexibility & $\begin{array}{l}0.115^{* * *} \\
(0.001)\end{array}$ & $\begin{array}{l}0.124 * * * \\
(0.000)\end{array}$ & $\begin{array}{l}0.131 * * * \\
(0.000)\end{array}$ & $\begin{array}{l}0.126^{* * *} \\
(0.000)\end{array}$ & $\begin{array}{c}0.146 \\
(0.082)\end{array}$ \\
\hline Stress & $\begin{array}{c}-0.107 * * * \\
(0.000)\end{array}$ & $\begin{array}{c}-0.118 * * * \\
(0.000)\end{array}$ & $\begin{array}{c}-0.104 * * * \\
(0.000)\end{array}$ & $\begin{array}{c}-0.111 * * * \\
(0.000)\end{array}$ & $\begin{array}{l}-0.188 * * * \\
(0.000)\end{array}$ \\
\hline
\end{tabular}


Appendix 2 cont.

\begin{tabular}{lccccc}
\hline & $<30$ & $30-40$ & $40-50$ & $50-60$ & $>60$ \\
& years & years & years & years & years \\
\hline Physical effort & -0.045 & -0.118 & $-0.036^{*}$ & $-0.041^{*}$ & 0.017 \\
& $(0.117)$ & $(0.000)$ & $(0.014)$ & $(0.043)$ & $(0.748)$ \\
Security at work & $0.137 * *$ & $0.187 * * *$ & $0.197 * * *$ & $0.202^{* * *}$ & $0.255^{*}$ \\
& $(0.002)$ & $(0.000)$ & $(0.000)$ & $(0.000)$ & $(0.054)$ \\
Over-education & $-0.192^{* * *}$ & $-0.120^{* * *}$ & $-0.107 * * *$ & $-0.151^{* * *}$ & 0.109 \\
& $(0.000)$ & $(0.000)$ & $(0.000)$ & $(0.000)$ & $(0.140)$ \\
Under-education & 0.038 & 0.032 & -0.041 & -0.060 & 0.050 \\
& $(0.668)$ & $(0.506)$ & $(0.361)$ & $(0.366)$ & $(0.746)$ \\
Household conditions & & & & & \\
\hline Hours used in housework & -0.009 & $0.046^{*}$ & 0.006 & -0.013 & -0.014 \\
& $(0.769)$ & $(0.011)$ & $(0.738)$ & $(0.550)$ & $(0.806)$ \\
Satisfaction with partner & & & & & \\
housework hours & $0.073 * *$ & $0.075^{* * *}$ & $0.063 * * *$ & $0.064 * * *$ & 0.055 \\
& $(0.006)$ & $(0.000)$ & $(0.000)$ & $(0.001)$ & $(0.353)$ \\
\hline
\end{tabular}

Note: * Significant at 10\%; ** Significant at 5\%; *** Significant at $1 \%$ level.

Other control variables included are occupation, region and year.

\section{APPENDIX 3}

Ordered probit. Marginal effects (JS=2)

$\begin{array}{ccc}<=\text { Primary } & \text { Secondary } \\ \text { studies } & \text { studies } & \begin{array}{c}\text { University and } \\ \text { post-university } \\ \text { studies }\end{array}\end{array}$

Personal characteristics

\begin{tabular}{lccc}
\hline Female & 0.046 & $0.072^{* * *}$ & $0.068^{* * *}$ \\
Age 30-40 years & 0.099 & 0.000 & 0.000 \\
& 0.056 & $-0.044^{*}$ & 0.023 \\
Age 40-50 years & 0.149 & 0.024 & 0.509 \\
& 0.003 & $-0.041^{*}$ & 0.004 \\
Age 50-60 years & 0.938 & 0.073 & 0.920 \\
& 0.004 & -0.021 & -0.046 \\
Age > 60 years & 0.926 & 0.433 & 0.294 \\
& 0.010 & 0.109 & 0.123 \\
Marital status: separated/divorced & 0.866 & 0.081 & 0.077 \\
& -0.016 & 0.037 & -0.046 \\
Marital status: married & 0.870 & 0.563 & 0.537 \\
& 0.061 & -0.003 & -0.020 \\
\hline
\end{tabular}


Appendix 3 cont.

\begin{tabular}{|c|c|c|c|}
\hline & $\begin{array}{c}<=\text { Primary } \\
\text { studies }\end{array}$ & $\begin{array}{l}\text { Secondary } \\
\text { studies }\end{array}$ & $\begin{array}{c}\text { University and } \\
\text { post-university } \\
\text { studies }\end{array}$ \\
\hline & 0.163 & 0.911 & 0.607 \\
\hline \multirow[t]{2}{*}{ Children } & $-0.051 *$ & -0.010 & -0.016 \\
\hline & 0.025 & 0.497 & 0.436 \\
\hline \multicolumn{4}{|l|}{ Objective nature job characteristics } \\
\hline \multirow[t]{2}{*}{ Managerial post } & 0.040 & $0.097^{*}$ & $0.119 * * *$ \\
\hline & 0.579 & 0.016 & 0.000 \\
\hline \multirow[t]{2}{*}{ Intermediate post with subordinates } & $0.083 * *$ & $0.046 * *$ & 0.037 \\
\hline & 0.002 & 0.002 & 0.057 \\
\hline \multirow[t]{2}{*}{ Self-employed } & -0.048 & 0.109 & 0.061 \\
\hline & 0.580 & 0.056 & 0.459 \\
\hline \multirow[t]{2}{*}{ Public sector workers } & 0.077 & 0.016 & $0.038^{*}$ \\
\hline & 0.004 & 0.304 & 0.042 \\
\hline \multirow[t]{2}{*}{ Temporary job } & -0.036 & 0.009 & 0.023 \\
\hline & 0.123 & 0.583 & 0.396 \\
\hline \multirow[t]{2}{*}{ Part-time job } & -0.030 & 0.031 & $-0.086^{* *}$ \\
\hline & 0.402 & 0.148 & 0.008 \\
\hline \multirow[t]{2}{*}{ Continuous day } & -0.001 & -0.019 & 0.004 \\
\hline & 0.957 & 0.107 & 0.810 \\
\hline \multirow[t]{2}{*}{ Sunday working days } & -0.058 & 0.009 & $0.141^{*}$ \\
\hline & 0.152 & 0.730 & 0.029 \\
\hline \multirow[t]{2}{*}{ Working day $>40$ hours } & 0.001 & 0.014 & 0.008 \\
\hline & 0.962 & 0.346 & 0.751 \\
\hline \multirow[t]{2}{*}{ Labour agreement } & 0.007 & 0.013 & 0.030 \\
\hline & 0.679 & 0.000 & 0.069 \\
\hline \multirow[t]{2}{*}{ Number of hours worked } & -0.056 & $-0.064^{*}$ & -0.054 \\
\hline & 0.199 & 0.039 & 0.316 \\
\hline \multirow[t]{2}{*}{$600<$ Wage $<1200$ euros } & 0.040 & $0.067 *$ & -0.018 \\
\hline & 0.345 & 0.014 & 0.784 \\
\hline \multirow[t]{2}{*}{$1200<$ Wage $<2100$ euros } & 0.084 & $0.110^{* * *}$ & 0.030 \\
\hline & 0.070 & 0.000 & 0.652 \\
\hline \multirow[t]{2}{*}{$2100<$ Wage $<3000$ euros } & 0.091 & $0.145 * * *$ & 0.017 \\
\hline & 0.061 & 0.000 & 0.797 \\
\hline \multirow[t]{2}{*}{$3000<$ Wage $<4500$ euros } & 0.083 & $0.139 * * *$ & 0.024 \\
\hline & 0.149 & 0.000 & 0.715 \\
\hline \multirow[t]{2}{*}{ Wage $>4500$ euros } & -0.049 & $0.365 * * *$ & 0.139 \\
\hline & 0.800 & 0.000 & 0.089 \\
\hline
\end{tabular}


Appendix 3 cont.

\begin{tabular}{|c|c|c|c|}
\hline & $\begin{array}{c}<=\text { Primary } \\
\text { studies }\end{array}$ & $\begin{array}{l}\text { Secondary } \\
\text { studies }\end{array}$ & $\begin{array}{l}\text { University and } \\
\text { post-university } \\
\text { studies }\end{array}$ \\
\hline \multicolumn{4}{|l|}{ Subjective nature job characteristics } \\
\hline \multirow[t]{2}{*}{ Satisfaction with promotion $(0-10)$} & $0.118 * * *$ & $0.140 * * *$ & $0.184 * * *$ \\
\hline & 0.000 & $(0.000)$ & 0.000 \\
\hline \multirow{3}{*}{$\begin{array}{l}\text { Satisfaction with job stability } \\
(0-10)\end{array}$} & & & \\
\hline & $0.141 * * *$ & $0.194 * * *$ & $0.139 * * *$ \\
\hline & 0.000 & 0.000 & 0.000 \\
\hline \multirow{3}{*}{$\begin{array}{l}\text { Satisfaction with personal } \\
\text { development }(0-10)\end{array}$} & & & \\
\hline & $0.327 * * *$ & $0.281 * * *$ & $0.398 * * *$ \\
\hline & 0.000 & 0.000 & 0.000 \\
\hline \multirow{3}{*}{$\begin{array}{l}\text { Satisfaction with senior levels } \\
(0-10)\end{array}$} & & & \\
\hline & $0.229 * * *$ & $0.200 * * *$ & $0.220 * * *$ \\
\hline & 0.000 & 0.000 & 0.000 \\
\hline \multirow{3}{*}{$\begin{array}{l}\text { Satisfaction with labour relations } \\
(0-10)\end{array}$} & & & \\
\hline & 0.030 & $0.158 * * *$ & $0.123 * * *$ \\
\hline & 0.537 & 0.000 & 0.004 \\
\hline \multirow[t]{2}{*}{ Satisfaction with timetable } & $0.200 * * *$ & $0.172 * * *$ & $0.177 * * *$ \\
\hline & 0.000 & 0.000 & 0.000 \\
\hline \multirow[t]{2}{*}{ Satisfaction with flexibility } & $0.120 * * *$ & $0.132 * * *$ & $0.123 * * *$ \\
\hline & 0.000 & $(0.000)$ & 0.000 \\
\hline \multirow[t]{2}{*}{ Stress } & $-0.101 * * *$ & $-0.123 * * *$ & $-0.102 * * *$ \\
\hline & 0.000 & 0.000 & 0.000 \\
\hline \multirow[t]{2}{*}{ Physical effort } & -0.038 & $-0.036^{* *}$ & -0.032 \\
\hline & 0.061 & 0.003 & 0.058 \\
\hline \multirow[t]{2}{*}{ Security at work } & $0.163 * * *$ & $0.201 * * *$ & $0.191 * * *$ \\
\hline & 0.000 & 0.000 & 0.000 \\
\hline \multirow[t]{2}{*}{ Over-education } & $-0.119 * * *$ & $-0.111^{* * *}$ & $-0.167 * * *$ \\
\hline & 0.000 & $(0.000)$ & 0.000 \\
\hline \multirow[t]{2}{*}{ Under-education } & 0.089 & -0.021 & $-0.184^{*}$ \\
\hline & 0.107 & 0.535 & 0.029 \\
\hline \multicolumn{4}{|l|}{ Household conditions } \\
\hline \multirow[t]{2}{*}{ Hours used in housework } & 0.021 & 0.022 & -0.026 \\
\hline & 0.295 & 0.092 & 0.241 \\
\hline \multirow[t]{2}{*}{$\begin{array}{l}\text { Satisfaction with partner housework } \\
\text { hours }\end{array}$} & $0.083 * * *$ & $0.072 * * *$ & $0.053 * *$ \\
\hline & 0.000 & 0.000 & 0.001 \\
\hline
\end{tabular}

Notes: * Significant at 10\%; ** Significant at 5\%;*** Significant at $1 \%$ level.

Other control variables included are occupation, region and year. 